\title{
A New Relationship Between Globalisation and Interest Representation*
}

\author{
Gaetano Fausto Esposito**
}

\begin{abstract}
What we have been witnessing for decades is a crisis of the organizations that represent both workers and employers. This paper examines some of the reasons for this situation in light of globalisation, and an increasingly limited State sovereignty which has led to its own loss of legitimacy. This paper also explores the changed scenario resulting from internationalisation, and offers indications for a different way of organising interests by combing the new demands for identity recognition with the expansion of market borders.
\end{abstract}

Keywords: Representation of Interests; Globalisation; Global Markets; Supranational Governance; Global Value Chain

\section{Globalisation and the Representation of Interests}

Side by side with the birth of globalisation, the start of the twenty-first century has witnessed a profound change in the role and involvement of the organisations that represent the interests of both employers and employees. The most severe economic crisis of the post-war period has sharpened the globalization process, along with the rise of different forms of sovereignty. The latter has been regarded by many as a way of countering the increasing inequality induced specifically by the development of globalisation. In many respects, these dynamics are also altering the structure of capitalist systems, thus leading one to reflect upon the longterm nature of the current phenomena, as well as upon the ongoing process that does not yet seem to have consolidated itself. Hence, this paper sets out to provide a few considerations on the role and the impact of the globalisation process, as well as the intensification of supranational governance systems, by evaluating their effects on the organisations performing interest representation roles.

The purpose is to assess whether the most recent trends, which seem to have been implemented to counterbalance this condition, can indicate a different interpretation of production and work representation. This is especially true as the present day network has a crucial and influential impact on the definition of systems that are profoundly different from the past, especially the most recent past. In consideration of a reserved approach at a national level, a proposal will be put forward that looks at representative figures as a means of promoting networking at a cross boarder level, on condition that they manage to overcome individual pressure in order to

\footnotetext{
* Invited Article

** Secretary General of the Association of Italian Chambers of Commerce Abroad (gfesposito@assocamerestero.it)
}

Edited by: Niccolò Cusano University

ISSN: 1593-0319

Esposito, G. F. (2019). A New Relationship Between Globalisation and Interest Representation. Symphonya. Emerging Issues in Management (symphonya.unicusano.it), 2, 72-81 
safeguard general interests.

\section{The Crisis of the Interest Representation Models}

Capitalist regimes share a common feature; they are less influential. Whether they are market-oriented (i.e. the Anglo-Saxon type), or traditional solidarity-oriented (i.e. similar to a European model, especially the German system) characterized by a greater participation and a higher level of concentration in relation to the interests of employers and employees, the majority of the representative figures are no longer able to offer a constructive and a greater contribution to the development process. This inability (even if only in terms of proposals put forth or by degree of influence) has recently been accompanied by the struggle to tackle the crisis that began in 2008. The general decline in unionisation levels among companies and employees is perhaps the most important descriptive aspect. From various stand points, we can say that a true crisis has upset traditional relations in the socialdemocratic capitalist systems featuring high levels of policy concentration and characterized by a "managed economy". Such crisis has produced a growing incapacity of the interest representative figures to perform their traditional role, i.e., interpreting and voicing the various needs of their members.

Is globalisation to blame for all of this? Recently, there has been a tendency to look at the drive towards the creation of a single global context as having a major role in creating a distance between political and civil society, thus increasing social inequality. Over the years, politics has been defined as guiding society in a certain direction according to an approach which responds to a logic of power (Crouch, 2013), whereas civil society is the manifestation of specific needs, which can be heard but not incorporated in the decision-making process. Reliable interaction between society and politics has long ensured a form of democracy, even if not in an obvious manner, whereby the coalition of interests found its own legitimacy in the ability to put forward general solutions to particular problems. In this manner, economic democracy, political democracy and capitalism have coexisted and nurtured one another through a bond that tied politics with work, and the business world with social change. For this reason, an approach that analyses only in economic terms is not sufficient to interpret these phenomena. Furthermore, it is also necessary to consider the changes brought about to the powers and the organization of individual national States, which have been generated by globalisation.

\section{The Crisis of the Representative Figures and National States}

In countries featuring a solidarity matrix (where neo-corporative capitalism manifested itself in different forms, such as Ordoliberalism in Germany), associations were essentially created with the purpose of protecting the interests of their members. This objective was pursued by bringing together the interests of groups and individuals and presenting them to political decision-makers who were responsible for implementing relative initiatives. Historically, in the Middle Ages, corporations and guilds, referring to individual trades and the arts, played an important role in consolidating productive know-how (Epstein, 1998). 
Nevertheless, they had to evolve into Universitas mercatorum, acquiring a higher degree of openness and intersectorial collaborations in order to develop a continuous learning process which in time led to the development of the Chambers of Commerce worldwide. Paradoxically, this evolution did not involve representative figures when times changed. Once adhering to a neo-corporative point of view, they ended up defending specific interests.

We can illustrate this interaction by focusing on the relationships of the three elements that in the past were defined as forms of regulation: society, market and governance. These relationships can be represented by a simple equilateral triangle in which each side influences the other and, in this case, has the same length (representing the strength of the relationship). When the three elements coincide significantly from a territorial point of view and in relation to the extension of their references, the relationships are balanced (Figure 1).

Figure 1: A Balanced Relationship Between Society, Market and Governance

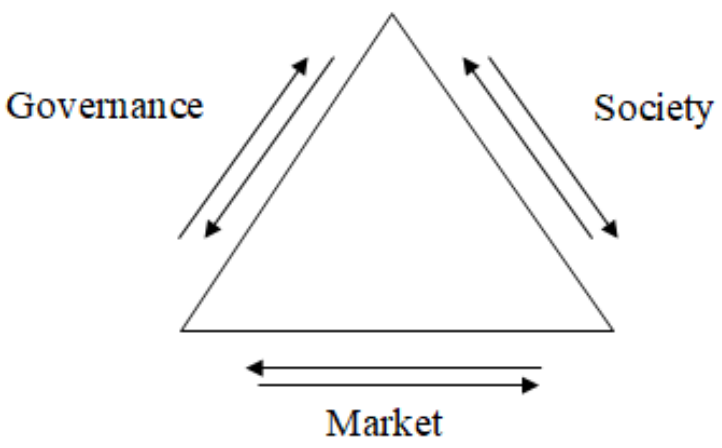

The representation system tries to interpret social demands which are influenced by the extent of the market and brings them to the attention of the policy makers who must adopt actions and measures accordingly. As pointed out by Acemoglu and Robinson, the political system undoubtedly appears to be the result of the work of the elite that also shape institutions, yet interaction is made possible by a substantially homogeneous reference among different forces.

Lobbying actions, especially defensive-like ones, find an easy balance in the capacity of government, which involves a system of balanced forces. An example of this is the Fordist regimes of the 1960s and the 1970s, which can be found even in countries characterized by a strong openness to market processes such as the United States. Nonetheless, this model also applies to other realities and forms of capitalism such as Italy. John Kenneth Galbraith's theory regarding the mitigating powers of the "new industrial state", put forward in the 1970s, is based on an agreement between trade unions and major businesses which then affected government action. Those were the years in which the globalization process was gaining fresh momentum. This was thanks firstly to a substantial boost from exports, so it was essentially a commercial type of globalization, and secondly, to the promotion of productive internationalization from multinationals based in the country that led the market at the time, namely the United States. It was all based on a substantial fixed exchange rate system which ensured a sort of market peace. 
The Fordist regime rested significantly on manufacturing. The processes of international division of labour were in place but they were governed by Vernon's product life-cycle theory, according to which relocation of production has a sequential character, even in the context of an expanding market. The demands of the members (both companies and workers) were well defined within a fairly simplified pattern. At a national level, public welfare policies contributed to easing social relations, providing protection to those pushed out of the labour market.

The first major change to this situation was the end of the fixed exchange rate system. However, there was another aspect that started to generate a real fracture thus paving the way for further problems, it was the distance. This then turned into a distinct separation between society, market and governance because of the growing power of supranational organisations and the appearance of a new form of lex mercatoria generated by the market and the bargaining system. The establishment of international business standards, the creation of the World Trade Organisation (and its initial successes in promoting multilateral agreements and favouring free trade), along with the central role assumed globally by new forms of coordination (for both products and services) undermined this model and in many respects the sovereignty of individual national States at a global level. At this point, the sides of the triangle lose their symmetry. When referring to the European Union, for example, we can see the divergence between market size (including globalization) and political dimension, with the latter becoming increasingly limited (Rodrik, 2018).

The economic integration process (i.e., growing globalization) takes place at a level that is increasingly less manageable by individual nations. This has a few exceptions and presents a hegemony which today appears clearly shifted towards the Asian axis rather than towards the Western one (Baldwin, 2018). It is accompanied by a growing erosion of traditional political-institutional channels which appear to be increasingly inadequate in implementing regulations capable of influencing production.

The economic crisis that began in 2008 contributed to the structural weakening of the representative organisations by dumping on them a demand for "solutions" that they were not able to deal with. Rather than reacting, these organisations lost sight of their true function and gave up on the task of favouring new forms of production having social value. In many cases, they intensified their degree of closure and decreased their defence of the interests and demands that globalisation, the global crisis, and the reduced State sovereignty were continuing to erase. As a result, representative organisations placed more emphasis on bureaucratic aspects. The more they lost their ability to interpret change and to find "networks" that moved beyond national frontiers and increased the level of global interaction, the less they were able to solve social conflicts. They were created to ensure diversity and the necessary flexibility of society, but instead these organizations became a contracting element, a point of close connection with national institutions, creating a gap in the vital circuits of a basic economy. In many respects, they became power management centres (that exercised and performed at a local level, on the basis of national legitimacy and not vice versa). In other words, they remained suspended between local demands and national regulation, with negative effects for all those involved. 
Robert Reich's observations regarding the American society are significant in this sense. When the vast mosaic of organizations that had given strength and meaning to American pluralism began to fall apart by the end of the $1980 \mathrm{~s}$, this led to the rise of a few pressure groups that decisively influenced legislative and government actions. Among these, the weight of large companies and their interests became absolutely predominant thanks to their capability of financing election campaigns. This consequently brought about an apparent form of neo-liberalism which was essentially functional towards the interests of the lobbies, but absolutely dysfunctional in terms of democracy. Politics has increasingly tended to represent the interests of that $1 \%$ of society in which $99 \%$ of wealth has accumulated (Stiglitz, 2015).

If we use the triangle metaphor again, we can see that now the relationships among the different elements can be geometrically interpreted with a scalene triangle (Figure 2). Here, the representative entities are caught between social needs that continue to be manifested on a substantially local and national level, and a State (and governance model) that is no longer able to give all the concrete answers to the needs of a growing market because it is heavily influenced by supranational institutions or by phenomena that are generally beyond its control.

Figure 2: Unbalanced Relationship Between Society, Market and Governance

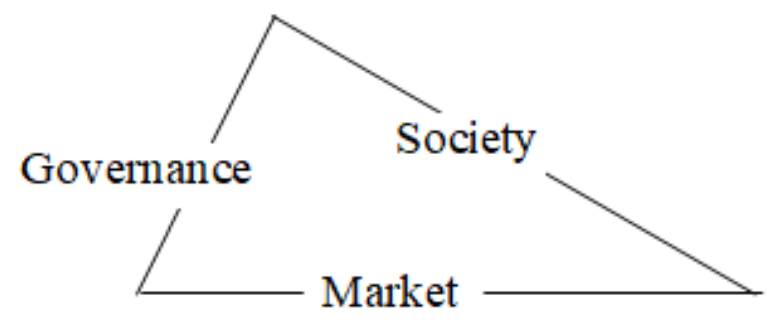

The consequence of this situation is the challenged stability of the Fordist model and of the economic and political interests of the representative organizations. The national government becomes a more articulated, complex and vague structure. Specifically, it breaks up into a type of multi-level governance so it can no longer interpret the system made up of associations and intermediate entities. Other hindering factors are the lack of international exposure, and a still excessively centralized coordination of the individual national States.

\section{Other Weakening Factors: The Relationship Between Global Value Chains and Services}

Alongside the social and institutional effects outlined above, globalisation has produced two further consequences that bear relevance in economic terms and that put pressure on the traditional function of representative organisations:

- the appearance of global value chains which have considerably eased trade relations worldwide; 
- the associated redefinition of business boundaries (Gaio et al., 2018) and the internal connections among the various sectoral components.

In reference to the first point, $70 \%$ of goods and services traded on the international market today involve exchanges between countries that can generally fit into the global value chains. This implies that exports between countries are based on complex interactions between domestic and foreign suppliers. Although the process in question is going through a redefinition phase, value chains are becoming less and less labour intensive and increasingly characterized by an abundant presence of advanced, professional skills and, therefore, more knowledge intensive (McKinsey \& Company, 2019). Permeability influences the same production process. First of all, services grow when looking at overall production to such an extent that cross border services rise $60 \%$ faster than the trade of goods. The increase of services is also driven by the development of digital platforms and, more in general, by the application of the Internet of Things (IOT), as well as of artificial intelligence (McKinsey \& Company, 2019).

While in the past it was possible to draw a line between manufacturing and the service component, today this boundary is increasingly vague. Consequently, it is difficult to define a clear profile of the individuals to represent, and accordingly, the role of representing interests falls through. Moreover, components possessing conflicting interests within the same global chain are frequent. With a few exceptions (e.g. China), this may also refer to an increasingly limited individual State sovereignty. As demonstrated in the past and today, both the "how to represent the interests" and the "who to represent" become problematic because of the failure of the economic effects of protectionist measures. Today, this is commonly interpreted as political signs of the struggle of claiming a global hegemony in several fields, such as that of new technologies. In other words, as the "value component" loses its identity from a physical point of view, and the intangible and creative interest of the global chains increases, it becomes more difficult for organizations to find an actual position of representation and thus to exercise their role. If we look at the reality of productive phenomena, not only in large multinationals but also in small and medium-sized enterprises, we realize the difficulty of defining productive roles in value chains with a continuous exchange of material and immaterial factors that Industry 4.0 and the widespread use of digital technologies have erased and rendered difficult to identify (Brondoni \& Zaninotto, 2018; Büchi et al., 2018). Specifically, genuine business platforms have appeared which are continuously redefining the vertical and horizontal business boundaries that identify a company (Gaio et al., 2018). Consequently, room for intermediation roles carried out at a national level tends to become increasingly narrow.

\section{Is This Process Irreversible?}

We have seen that there is a widely accepted belief according to which globalization is generating growing inequalities in each country per se, and this is the result of a process aimed at improving the standards of living. Strictly speaking, inequality has decreased worldwide (thanks to globalization), but it has increased 
within each country individually (Rodrik, 2017). Furthermore, the middle class in the Western world has experienced a decline in income distribution in favour of the world's richest $1 \%$, which today accounts for $29 \%$ of total income and $46 \%$ of global wealth. Accordingly, the impoverishment of the middle classes has given new momentum to defensive attitudes and the demand for protection.

Observing the aftermath in two countries characterised by market capitalism (the United States and the United Kingdom) we can see a strong social desire towards regaining individual sovereignty and protection, and this has also been reflected in a political context. This interpretation may be drawn from the large segments of the population (even if localized in specific areas of the countries) which protest against the impoverishing effects of globalisation. (Ottaviani, 2019). The basis of this argument is that when a phenomenon is beyond the national range, there is the risk of cracking under the pressure of supranational organization elites. There are also various important individuals, such as Dani Rodrik, who believe that the near future will witness a return to nationwide policies, while engaging in lighter forms of co-ordination at an international level. There are however oppositions to this theory; Colin Crouch, for example, believes the opposite. In any case, even if single States regain authority in the years to come, because of disappointing results achieved by international institutions in managing certain "global" issues, the situation is far from seeing a return to the past, and any attempt to do so may end up making the role of interest representation even more complex. The reason being is that it is sided by direct forms of interaction among national governments and administered entities that bypass the action and the role of intermediate groups which risk being regarded as poorly functional institutions.

From a political point of view, when local demands arise within individual countries, renewed attention seems to be given to the role of local institutions. Perhaps, it is precisely because of this, and in light of increasingly global interests, that figures representing the interests of employers and, in many cases, those of workers, should act at a supranational level and within a network, in order to develop an approach for supply chains and value chains that requires an innovative step forward and a governance that radically changes established patterns.

\section{Concluding Remarks and Proposals}

This paper has briefly outlined how the crisis of the organizations representing employers and employees can be attributed to different causes. While they can widely be the result of globalisation, the underlying reasons are in fact related to the manner in which the structures of these representative organisations have developed over time with regards to their role and behaviour.

As for the first aspect, there is no doubt that the role of the government on a national level has changed. As its specific features are still undefined, it has the consequent need of more articulated governance. This is a process that needs to be faced and dealt with. Moreover, it has recently experienced a standstill because of the reaction of national populism entities, which have however influenced political actions more than economic-social ones. We cannot assume that the world can be governed by the market. For some years now, Stiglitz and Rodrik, among others, 
have been reporting the anomalies of hyper-globalization and turbo-capitalism that have become extractive processes of value rather than devices for its creation (let alone its popularity).

It is precisely because these demands arise, that the associations that represent (or would like to represent) the complex web of productive interactions should avoid supporting the political pressures that tend to bypass them. In fact, they should instead promote the openness and networking that are completely missing and that are often denied because of political needs. If these organisations were to succeed, they could also create a mediating entity to handle new regional policies, even those having a European imprint. This would promote networks with a trust-based relationship between businesses and institutions for employers (Esposito, 2018). Global value chains, the increase of services in the production system, the removal of boundaries between companies, collaborations between production and services for the sake of creativity, various forms of additive manufacturing etc., should be placed at the heart of representation. It must consider consensus. Nevertheless, when referring to productive forces, the aim should be to increase the overall process of value creation, for both workers and employers, and to hold greater flexible positions than in the past. It would be necessary to move towards a representation embodying the value creation processes and the various actors who have a role in it. Therefore, it is vital to leave behind the opposition principle, the "politics of resentment" and the difficulty of the middle and lower middle classes mentioned by Francis Fukuyama, and instead adopt a shared logic, a more articulated approach which eliminates traditional distinctions among sectors, as this classification is of no use in the global creation of value. What is needed is a form of representation of global interests that makes its voice heard not so much by individual national States, as was the case in the past, but by all those contexts in which new market rules and the new lex mercatoria ${ }^{1}$ have been consolidated. This type of affiliation is mediated by the role played by networks and, to some extent, by different associative, business, and social entities. It is not about considering whether to move the traditional organizations outside the national State, because this would simply be reintroducing a superseded model. Instead, we need to radically reconsider them as representative of the value creation process.

So, does everyone need to see it in the same manner? Absolutely not. Globalization itself is giving rise to, and pointing out differences in the quest for common aspects. In fact, the European Union's Smart Specialization Strategy itself should be viewed as the interaction between local and global networks (Bellini, 2015). It is precisely the increase of numerous individual affiliations during globalisation that makes the unification process carried out by intermediate entities even more significant. Each of us belongs to several communities; some are virtual while others are real. In a true democracy, it is impossible to imagine that this task, which calls for actual participation, can take place only through relations created in the network because of its impersonal and unverifiable nature. When people have the possibility of choosing between alternative identities and assigning them priorities, it increases their sense of freedom (Crouch, 2019).

What did not work in the intermediate entities was not their role, but often the forms of organization that they gave themselves. They prioritized structure over function, the protection of the organization over openness and social innovation, the 
lack of clarity in decision-making over the actual implementation of results, the (failed) ambitions to compensate for (political) roles that were not theirs (or for which they were not suitable) over the genuine representation of specific, greater interests.

Consequently, the need to create a strategy arises. In this respect, it may be useful to look at the field of professional services, which is traditionally more inclined to benefit from the connections and the resources provided by the network. Restoring a role rests on the creation of associations which are global and interconnected. They can even be organised locally, but with an international outlook. This task is far from easy, however, it can be performed by acting as an entity that pursues interests which are not bound to specific areas, but whose local aspect should in any case be promoted and can sometimes still convey a feeling of belonging and distinctiveness. This is possible thanks to the emerging phenomenon of a sense of identity and belonging, which is also the response to the misleading idea that globalisation rhymes with standardisation (Crouch, 2019; Fukuyama, 2018). Recent political episodes have shown that often, in a globalised world, the sense of national belonging unites people more than the business sectors they belong to. Global value chains strengthen the bond of belonging to multiple communities, and increase the compatibility of the productive advantages in the specialisation process that takes place on a global scale. They can hold together the "local" and the "global" scales to such an extent that we frequently talk about "glocalization" as a way of developing interaction among various entities which were once regarded incompatible. Representative associations should draw encouragement from this phenomenon and adjust their structure and their way of interacting. This is especially true in a world where local dimensions can coexist with the global network, and where the criteria used to gather problems and find answers cannot fall on individual solutions.

Reference models that provide insights into new forms of organisation which bring together local and global dimensions already exist. The Chamber of Commerce is a noteworthy example of a reference model. They are recognised nationally and internationally and have the ability of representing business associations that operate in a global network. American, French, German, and Italian Chambers located abroad are a good example. They are transversal in nature, represent businesses and professionals from different industries, and operate with organizations that contribute to a network-like structure at a supranational level.

When asked whether globalisation negatively affects entities representing productive interests, the answer is that globalisation makes traditional organisational structures obsolete. At the same time, it also prompts one to find new forms and procedures for representing these interests by using the development of global processes of value creation itself.

\section{Bibliography}

Acemoglu, D. \& Robinson, J. A. (2012). Why Nations Fail. The Origin of Power Prosperity and Poverty, Crown Publishers, New York. 
Baldwin, R. (2016). The Great Convergence. Information Technology and the New Globalization, Cambridge University Press, Cambridge MA.

Bellini, N. (2015). Smart Specialisation in Europe: Looking Beyond Regional Borders, Symphonya. Emerging Issues in Management (symphonya.unimib.it), (1), 22-29.

http://dx.doi.org/10.4468/2015.1.03bellini

Brondoni S.M., (2018). Planned Obsolescence, Total Quality, Zero Defects and Global Competition, Symphonya. Emerging Issues in Management (symphonya.unimib.it), (2), 8-20.

http://dx.doi.org/10.4468/2018.2.02brondoni

Brondoni, S. M. \& Zaninotto, E. (2018). Ouverture de "The 4th Industrial Revolution. Business Model Innovation \& Global Competition, Symphonya. Emerging Issues in Management (symphonya.unimib.it), (2), 1-7.

http://dx.doi.org/10.4468/2018.2.01ouverture

Büchi, G., Cugno, M. \& Castagnoli, R. (2018). Economies of Scale and Network Economies in Industry 4.0, Symphonya. Emerging Issues in Management (symphonya.unimib.it), (2), 66-76. http://dx.doi.org/10.4468/2018.2.06buchi.cugno.castagnoli

Crouch, C. (2019). The Globalization Backlash, Polity press, Cambridge, UK.

Crouch, C. (2013). Making Capitalism Fit for Society, Press Cambridge, UK.

Epstein, S. R. (1998). Craft Guilds, Apprenticeship, and Technological Change in Pre-industrial Europe, The Journal of Economic History, 3, 684-713.

http://dx.doi.org/10.1017/S0022050700021124

Esposito, G. F. (2018). Development Policies for Lagging Behind Areas: An Interpretative Note in the Name of Civil Entrepreneurial Development, Journal of Economic Behavior, 8, 33-45. Available at http://ijeb.faa.ro/en/volumes/IJEB--2018-vol-8 96.html

Fukuyama, F. (2018). Identity: The Demand for Dignity and the Politics of Resentment, Farrar, Straus \& Giroux, New York.

Gaio, L., Rossi, A. \& Zaninotto, E. (2018). Growth Through Metamorphosing, Symphonya. Emerging Issues in Management (symphonya.unimib.it), (2), 21-37.

http://dx.doi.org/10.4468/2018.2.03gaio.rossi.zaninotto

Galbraith, J. K. (1967). The New Industrial State, Princeton University Press. Princeton.

McKinsey \& Company (2019), Globalization in Transition: The Future of Trade and Value Chains. January.

Reich, R. B. (2015). Saving Capitalism. For the Many Not the Few, Deckle Edge.

Rodrik, D. (2018). Straight Talk on Trade. Ideas for a Sane World Economy, Princeton University Press, Princeton

Rodrik, D. (2017). Is Global Equality the Enemy of National Equality? HKS Working Paper No. RWP17-003.

http://dx.doi.org/10.2139/ssrn.2910603

Stiglitz, J. E. (2015). The Great Divide. Unequal Societies and What We Can Do About Them, WW Norton\&Co, New York.

Vernon, R. (1971). Sovereignty at Bay: The Multinational Spread of U.S. Enterprises, Basic Books, New York.

\section{Notes}

${ }^{1}$ These are contracts which are widely distributed at an international level and are not drawn up by national lawmakers, but by the legal offices of large multinationals or by consultants of international associations of certain businesses. 